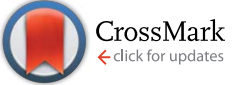

Cite this: RSC Adv., 2017, 7, 1759

\title{
Half-sandwich chiral rare-earth metal complexes with linked tridentate amido-indenyl ligand: synthesis, characterization, and catalytic properties for intramolecular hydroamination $\uparrow$
}

\author{
Zhuo Chai, Jiang Chu, Yunyi Qi, Mujun Tang, Jinsong Hou and Gaosheng Yang*
}

The enantioselective intramolecular hydroamination of alkenes with free amines has been a touchstone reaction in the development of many new chiral rare-earth (RE) metal complexes. In this article, we describe the synthesis and characterization of four novel rare-earth metal (Y, Sm, Lu, Sc) complexes, featuring a tridentate carbon-linked amido-indenyl ligand with a shortened linker between the indene ring and the chiral diamine moiety, as compared to our previously developed structurally similar siliconlinked ligand. Despite the generally lower enantioselectivities obtained in the current work, the structure-activity analyses of these complexes based on X-ray crystallographic data could be useful for further development of highly efficient chiral rare-earth metal complexes for asymmetric synthesis.

Received 9th November 2016 Accepted 15th December 2016

DOI: 10.1039/c6ra26537e

www.rsc.org/advances
$C_{1}$-symmetric chiral sandwich ligands, ${ }^{3,4}$ chemists have developed numerous alternative non-Cp based chiral ligands that can circumvent this issue, including chiral $\mathrm{BINOL}^{7} / \mathrm{BINAM}^{8}$ based ligands, chiral vicinal diamine based ligands ${ }^{9}$ and others, ${ }^{10}$ with impressive advances being achieved. On the other hand, the development of half-sandwich rare-earth metal complexes with $\mathrm{Cp}$ ligands bearing a short side arm containing additional chelating functionalities, known as constrained geometry complexes (CGCs), has received much interest with some unique structures and reactivities being disclosed. ${ }^{11}$ However, the development of chiral CGCs of rare-earth metals, which could serve as precatalysts for asymmetric synthesis, has been rarely reported.

In this context, our group have recently demonstrated that chiral yttrium complex 1 bearing a tridentate silicon-linked amido-indenyl ligand could catalyse the intramolecular hydroamination of non-activated olefins with up to $97 \%$ ee (Fig. 1). ${ }^{6}$ However, the poor crystallinity of complexes of this ligand with other rare-earth metals hampers a thorough structure-reactivity study with these complexes. Moreover, similar to many other

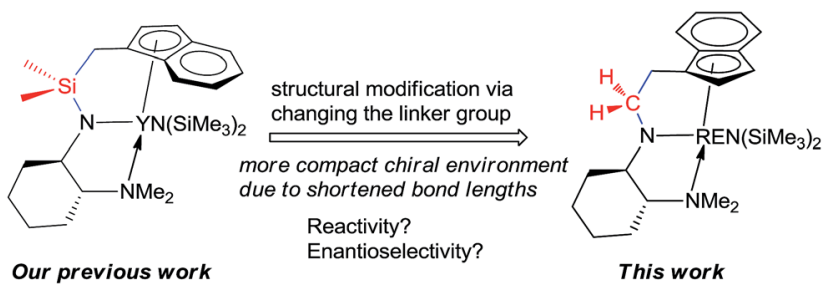

Fig. 1 Chiral half-sandwich RE metal complexes for intramolecular annulative hydroamination of unactivated olefins.
Key Laboratory of Functionalized Molecular Solids, Ministry of Education, Anhui Laboratory of Molecule-Based Materials, Institute of Organic Chemistry, College of Chemistry and Materials Science, Anhui Normal University, Wuhu, Anhui 241000, China. E-mail: gshyang@mail.ahnu.edu.cn

$\dagger$ Electronic supplementary information (ESI) available: Crystallographic data in CIF files, copies of NMR spectra and HPLC traces. CCDC 1509830, 1509831, 1509832 and 1509833. For ESI and crystallographic data in CIF or other electronic format see DOI: 10.1039/c6ra26537e 
chiral rare-earth metal complexes examined in this reaction, the degrees of enantiocontrol achieved with this complex varied significantly from one substrate to another one, even in cases with only minor structural changes. It is presumed that replacing the silicon linker by a smaller carbon one might create a more compact chiral environment around the metal center, which may have significant influence on the reactivity and/or chiral induction power of the corresponding RE metal complexes. ${ }^{12}$ Herein, we report the results of our research efforts in this regard.

\section{Results and discussion}

\section{Syntheses and characterization}

Our study began with the syntheses of the complexes 4 (Scheme 1). First, condensation of 2-(1H-inden-3-yl)acetic acid 1 with the commercially available chiral diamine provided chiral amide 2 in $83 \%$ yield, which was then reduced with lithium aluminium hydride to furnish the desired methylene-linked indene-chiral diamine ligand 3 in a yield of $69 \%$. Subsequent treatment of this ligand with $\left[\left(\mathrm{Me}_{3} \mathrm{Si}\right)_{2} \mathrm{~N}\right]_{3} \mathrm{Ln}(\mu-\mathrm{Cl}) \mathrm{Li}(\mathrm{THF})_{3}$ ( $\mathrm{Ln}$ $=\mathrm{Y}, \mathrm{Sm}, \mathrm{Lu}, \mathrm{Sc})$ in toluene furnished the corresponding chiral rare-earth complexes $\mathbf{4 a - 4 d}$ in excellent yields. The high overall yields for the preparation of this type of complexes provide an obvious advantage over our previously developed relevant silicon-linked complexes. ${ }^{6}$ All of the four complexes were characterized by NMR and elemental microanalysis. Moreover, the good crystallinities of these complexes allows for a more systematic single crystal X-ray crystallographic analyses, which could provide more useful insights to the structure-activity relationship (Fig. 2).

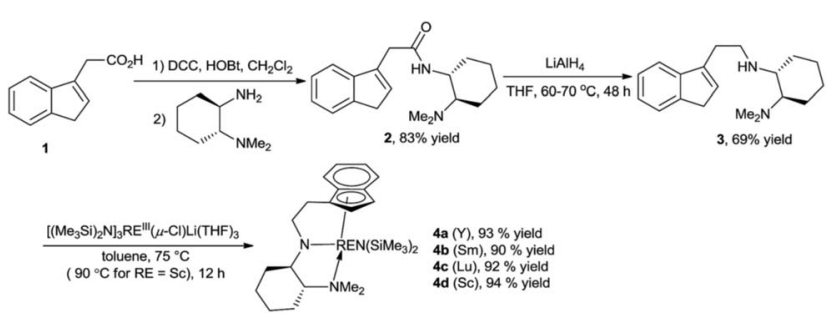

Scheme 1 Syntheses of the chiral rare-earth metal complexes 4.

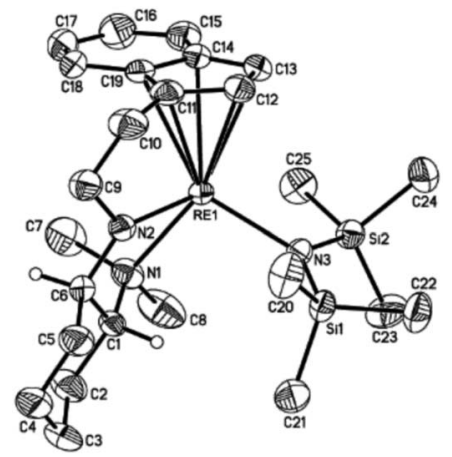

Fig. 2 ORTEP representation of RE complexes 4 (drawn with 30\% probability ellipsoids). $\mathrm{RE}=\mathrm{Y}, \mathrm{Sm}$, Lu or Sc.

\section{Description of crystal structures}

The X-ray structures of the four complexes are very similar, differing in only the core rare-earth metal. They all crystallized as mononuclear structures in the monoclinic space group $P 2_{1}$ with four molecules in the unit cell, and the rare-earth metal atoms are about in a tetrahedral coordination.

As shown in Table 1, the M-C bond lengths of 4 (2.467(3)$2.770(3) \AA$ ) between the rare-earth metal atoms and the indenyl carbon atom correlate well with those of related complexes previously reported by us and others. The covalent $\mathrm{M}-\mathrm{N}$ bond lengths (M-N2 and $\mathrm{M}-\mathrm{N} 3)$ are appreciably shorter than noncovalent ones (M-N1). Moreover, an apparent lanthanide contraction effect is observed on both the bond distances and bond angles: as the radii of the rare-earth metal atoms decreases, both the $\mathrm{M}-\mathrm{C}$ and $\mathrm{M}-\mathrm{N}$ bond lengths decreases while the bond angles of $\mathrm{N}-\mathrm{M}-\mathrm{N}$ bonds involving the two nitrogen atoms of the chiral ligand (N1 and N2) increases. Compared to our previous work with the chiral yttrium (Y) complex of the silicon-linked amido-indenyl ligand, the bond lengths of the two yttrium complexes, C9-C10 (1.512(6)) vs. Si-C (1.881(4)) and C9-N2 (1.471(6)) vs. Si-N (1.710(3)), would render the indene ring and the chiral diamine moiety closer as expected.

Another structural feature of complexes 4 isolated in this work resides in the planar chirality of the indene ring. In previous work with the rare-earth metal complexes of the chiral tridentate amido-indenyl ligand, we observed two different orientations of the indene ring in the complexes depending on the rare-earth metal ion ( $S_{\mathrm{p}}$ for Y and $R_{\mathrm{p}}$ for Er). In the current work, only one is observed in all of the four complexes with the absolute configuration of the indene ring being $R_{\mathrm{p}}$ irrespective of the metal core. This observation suggests the carbon-linked chiral ligand might predominate in determining the coordination orientation of the indene ring in these complexes.

\section{Catalysis of reaction}

With the chiral rare-earth metal complexes in hand, we then evaluated their catalytic activities in the intramolecular annulative hydroamination of aminoalkene $\mathbf{5 a}$ (Table 2). Complex $4 \mathbf{d}$ with the smallest ion radii of the core metal (Sc) demonstrated

Table 1 Selected bond lengths $(\AA)$ and angles $\left(^{\circ}\right)$ of complexes 4

\begin{tabular}{lllll}
\hline & 4a $(\mathrm{Y})$ & $\mathbf{4 b}(\mathrm{Sm})$ & $\mathbf{4 c}(\mathrm{Lu})$ & 4d (Sc) \\
\hline C11-RE & $2.611(4)$ & $2.667(3)$ & $2.568(4)$ & $2.476(2)$ \\
C12-RE & $2.630(4)$ & $2.715(3)$ & $2.576(4)$ & $2.467(3)$ \\
C13-RE & $2.682(4)$ & $2.760(3)$ & $2.629(5)$ & $2.523(3)$ \\
C14-RE & $2.716(4)$ & $2.770(3)$ & $2.678(4)$ & $2.609(2)$ \\
C19-RE & $2.679(4)$ & $2.729(3)$ & $2.660(4)$ & $2.588(2)$ \\
N1-RE & $2.487(3)$ & $2.558(2)$ & $2.423(3)$ & $2.343(2)$ \\
N2-RE & $2.171(3)$ & $2.226(2)$ & $2.132(3)$ & $2.029(2)$ \\
N3-RE & $2.238(3)$ & $2.301(2)$ & $2.193(3)$ & $2.087(2)$ \\
C9-C10 & $1.512(6)$ & $1.520(5)$ & $1.526(6)$ & $1.512(5)$ \\
C9-N2 & $1.471(6)$ & $1.456(4)$ & $1.452(5)$ & $1.474(3)$ \\
N1-RE-N2 & $73.52(12)$ & $71.84(8)$ & $75.39(12)$ & $77.93(8)$ \\
N1-RE-N3 & $101.44(12)$ & $102.28(9)$ & $100.73(12)$ & $99.80(8)$ \\
N2-RE-N3 & $113.63(11)$ & $113.42(7)$ & $113.01(11)$ & $114.88(8)$
\end{tabular}


the poorest activity and enantioselectivity, while complex $\mathbf{4 b}$ with the largest samarium ion is the most reactive one yet still with a very poor enantioselectivity. The absolute configuration of the product was assigned based on comparison of peak orders in HPLC assay on a chiral column with literature data. ${ }^{6}$

The complex $\mathbf{4 c}$ of lutetium (Lu) displayed the highest enantioselectivity for the reaction, albeit with a moderate catalytic efficiency (entry 3 ). These results suggest that a good match

Table 2 Evaluation of precatalysts $4^{a}$

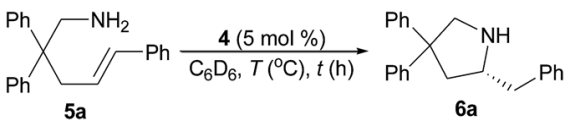

\begin{tabular}{lllrl}
\hline Entry & $\mathbf{4}(\mathrm{Ln})$ & $T\left({ }^{\circ} \mathrm{C}\right)$ & $t(\mathrm{~h})$ & $\mathrm{ee}^{b}(\%)$ \\
\hline 1 & $\mathbf{4 a}(\mathrm{Y})$ & 20 & 5.0 & 67 \\
2 & $\mathbf{4 b}(\mathrm{Sm})$ & 20 & 2.0 & 34 \\
3 & $\mathbf{4 c ~ ( L u )}$ & 20 & 29.0 & 87 \\
4 & $\mathbf{4 d ~ ( S c )}$ & 80 & 50.0 & 30
\end{tabular}

${ }^{a}$ Unless otherwise noted, the reactions were conducted with $0.27 \mathrm{mmol}$ of aminoalkene $5 \mathrm{a}$ in $0.5 \mathrm{~mL}$ of $\mathrm{C}_{6} \mathrm{D}_{6}$. All conversions are $>95 \%$ based on ${ }^{1} \mathrm{H}$ NMR analysis using ferrocene as the internal standard. ${ }^{b}$ Determined by chiral HPLC after acylation of the product $\mathbf{6 a}$ to the corresponding amide $7 \mathbf{a}$ with 4- $\mathrm{MeOC}_{6} \mathrm{H}_{4} \mathrm{COCl}$.

Table 3 Substrate scope study with precatalyst $4 a^{a}$

\begin{tabular}{|c|c|c|c|c|}
\hline Entry & Substrate & Product & $t(\mathrm{~h})$ & $\mathrm{ee}^{c}(\%)$ \\
\hline 1 & & & $5.0(9.6)^{b}$ & $67(97)^{b}$ \\
\hline 2 & & & $3.0(0.8)$ & $60(85)$ \\
\hline $3^{d}$ & & & $16.0(15.6)$ & $45(69)$ \\
\hline 4 & & & $4.0(13.0)$ & $56(82)$ \\
\hline $5^{d}$ & $5 \mathrm{e}$ & be & $50.0(9.0)$ & $52(80)$ \\
\hline $6^{d}$ & & & $68.0(9.6)$ & $41(58)$ \\
\hline 7 & & & $0.6(0.6)$ & 65 (75) \\
\hline $8^{d}$ & & & $10.0(62.1)$ & $43(72)$ \\
\hline
\end{tabular}

${ }^{a}$ See footnote $a$ of Table 2 for general reaction conditions. Reactions were run at $20{ }^{\circ} \mathrm{C}$ unless specified otherwise. ${ }^{b}$ Data in parentheses refer to those obtained with the silicon-linked yttrium complex, see ref. $6 .{ }^{c}$ Determined by chiral HPLC after acylation of the products 6 to the corresponding amides 7 with $4-\mathrm{MeOC}_{6} \mathrm{H}_{4} \mathrm{COCl} .{ }^{d}$ Run at $60{ }^{\circ} \mathrm{C}$. of the sizes of the metal ion and the chiral ligand is crucial for both reactivity and enantioselectivity.

For a direct comparison of catalytic power between the carbon-linked complex and the previously developed siliconlinked one, we first probed the substrate scope of $\mathbf{4 a}$, in spite of the moderate enantioselectivity obtained (Table 3). In terms of enantioselectivity, the carbon-linked yttrium complex $\mathbf{4 a}$ is invariably much inferior to the silicon-linked one, but they behaved quite similarly in responses to changes in the substrate structures. Moreover, their differences in catalytic efficiency varied from substrate to substrate, and in some cases 4 a proved to be much more favoured in this regard (entries 1, 4 and 8).

Next, we examined the substrate scope with complex 4c, the optimum precatalyst of the carbon-linked ligand series

Table 4 Substrate scope study with precatalyst $4 c^{a}$

Entry

${ }^{a}$ See footnote $a$ of Table 2 for general reaction conditions. Reactions were run at $20{ }^{\circ} \mathrm{C}$ unless specified otherwise. ${ }^{b}$ See footnote $b$ of Table 2 for general reaction conditions. Reactions were run at $20{ }^{\circ} \mathrm{C}$ unless specified otherwise. ${ }^{c}$ Run at $60{ }^{\circ} \mathrm{C} .{ }^{d}$ Run at $50{ }^{\circ} \mathrm{C}$. 
(Table 4). This complex provided higher enantioselectivity in the formation of five-membered pyrrolidines $\mathbf{6 a}$ and $\mathbf{6 b}$ (entries 1 and 2), as compared to the results obtained with the yttrium complex $\mathbf{4 a}$, while a slightly lower ee value was obtained in the case of six-membered piperidine $\mathbf{6 c}$ (entry 3 ). Given the high enantioselectivity obtained with $\mathbf{5 a}$, we then studied the substituent effect of the benzene ring on the reaction by examining several substituted styrene-type aminoalkenes. It is worth mentioning that systematic examination of this type of internal alkenes in rare-earth metal-catalysed asymmetric hydroamination reactions is unprecedented. Both the electronic nature and positions of the substituents on the benzene ring showed significant influence on the reaction rate and enantioselectivity. When the substituent is at the para position, an electron-withdrawing one, such as a halogen, is clearly favoured over an electron-donating one in terms of enantioselectivity (entries 5, 7 vs. entries 8, 9). The meta or ortho positions are not favoured when an electron-withdrawing substituent is present. Surprisingly, the meta position is mostly favoured in the case of $\mathbf{5 p}$ bearing a strongly electron-donating group (entry 11). The catalytic efficiency of the complex in these reactions, however, showed no consistent trend.

\section{Mechanistic consideration}

In view of the experimental results and previous relevant studies, ${ }^{2}$ a tentative reaction mechanism was proposed using the reaction of aminoalkene $\mathbf{5 b}$ as example (Scheme 2). First, upon the mixing of the chiral rare-earth metal complexes 4 and aminoalkene $\mathbf{5 b}$, a fast ligand exchange occurred to provide the intermediate $\mathbf{I}$, which would undergo intramolecular hydroamination to provide intermediate II. This intermediate would undergo protonation with the substrate $\mathbf{5 b}$ to release the cyclized product $\mathbf{6 b}$ while regenerating the intermediate $\mathbf{I}$. The stereochemical results of the reaction might be explained by the transition state model TS, which is based on the X-ray structures of $\mathbf{4}$. In this model, the main chain of $\mathbf{5 b}$ adopts a chair-like conformation with the bulky diphenyl substituents

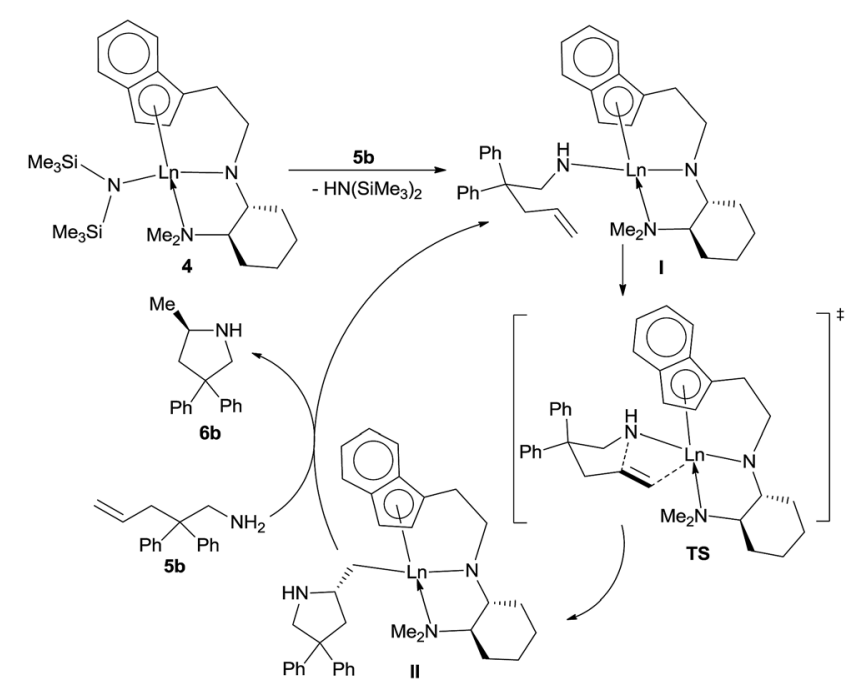

Scheme 2 Proposed reaction mechanism. far away from the chiral diamine backbone, and the nitrogen atom would attack the $S_{\mathrm{i}}$ face of the alkene as mediated by the rare-earth metal centre to provide the $R$-configuration product. We suppose that the inferior enantiocontrolling power of these complexes, as compared to the silicon-linked one, might be partly attributed to the chiral planarity $\left(S_{\mathrm{p}}\right)$ of the indene ring. In the current case, the phenyl group of the indene ring is placed away from the chiral diamine backbone, which might be detrimental to the synergy of these two chiral elements of the complex in the enantiodifferentiating process. However, a more exact rationale for the highly fluctuating enantioselectivity of this reaction system requires further in-depth investigation.

\section{Conclusions}

In summary, we have synthesised and characterized four novel chiral half-sandwich rare-earth metal complexes featuring a carbon-linked tridentate indene-diamine ligand. When used as precatalysts for the intramolecular hydroamination of unactivated alkenes, these complexes demonstrated significantly varied catalytic activity to provide the chiral pyrrolidine and piperidine products in moderate to good enantioselectivities. Although such results are not up to our expectation for the new carbon-linked ligand featuring a shortened linker between the indene ring and the chiral diamine moiety as compared to our previously developed structurally similar silicon-linked tridentate indene-diamine ligand, the structure-activity analyses of these complexes based on X-ray crystallographic data provide some useful information for further development of highly efficient chiral rare-earth metal complexes for asymmetric catalysis. Efforts towards this are currently underway in our laboratories.

\section{Experimental section}

\section{General methods}

All reactions with air- or moisture sensitive materials were performed in oven $\left(120^{\circ} \mathrm{C}\right)$ or flame-dried glassware under an inert atmosphere of argon, employing standard Schlenk and glovebox techniques. All solvents were distilled over either finely divided $\mathrm{LiAlH}_{4}$ or sodium benzophenone ketyl under argon prior to use unless otherwise noted. $\mathrm{CDCl}_{3}$ was dried over activated $4 \AA$ molecular sieves. $\mathrm{C}_{6} \mathrm{D}_{6}$ was distilled from sodium/benzophenone ketyl. $\left[\left(\mathrm{Me}_{3} \mathrm{Si}\right)_{2} \mathrm{~N}\right]_{3} \operatorname{Ln}(\mu-\mathrm{Cl}) \mathrm{Li}(\mathrm{THF})_{3}$ was prepared by a literature method. ${ }^{13}(1 R, 2 R)-N, N$ Dimethylcyclohexane-1,2-diamine is commercially available or could be prepared by using literature method. ${ }^{\mathbf{1 4}}$ All the aminoalkene substrates were synthesized according to literature protocols. ${ }^{15}$ Elemental analysis data were obtained with a Perkin-Elmer 2400 Series II elemental analyzer. ${ }^{1} \mathrm{H}$ NMR and ${ }^{13} \mathrm{C}$ NMR spectra for analyses of compounds were recorded with a Bruker AV 300 NMR or AVANCE-500 spectrometers in $\mathrm{C}_{6} \mathrm{D}_{6}$ or $\mathrm{CDCl}_{3}$. High performance liquid chromatography (HPLC) analyses were performed on a Agilent 1200 chromatograph using chiral Daicel Chiralcel® columns as noted. 


\section{Syntheses}

Amide (2). $N, N^{\prime}$-Dicyclohexylcarbodiimide (DCC, $2.54 \mathrm{~g}, 12.3$ $\mathrm{mmol})$ was added to a stirred solution of 2 -(1H-inden-3-yl)acetic acid (1.43 g, $8.2 \mathrm{mmol}$ ) and 1-hydroxybenzotriazole (HOBt, $1.99 \mathrm{~g}, 14.7 \mathrm{mmol})$ in $\mathrm{CH}_{2} \mathrm{Cl}_{2}(30 \mathrm{~mL})$ at $0{ }^{\circ} \mathrm{C}$ under argon and the resultant mixture was stirred overnight. The precipitate was filtered and washed with $\mathrm{CH}_{2} \mathrm{Cl}_{2}(10 \mathrm{~mL} \times 2)$. The filtrate was added to a solution of $(1 R, 2 R)-N, N$-dimethylcyclohexane-1,2diamine (1.06 g, $7.4 \mathrm{mmol})$ in $\mathrm{CH}_{2} \mathrm{Cl}_{2}(50 \mathrm{~mL})$ at $0{ }^{\circ} \mathrm{C}$ under argon. The resultant mixture was stirred at room temperature for $30 \mathrm{~h}$. Then, saturated aqueous $\mathrm{Na}_{2} \mathrm{CO}_{3}(20 \mathrm{~mL})$ was added, followed by stirring for $0.5 \mathrm{~h}$ to quench the reaction. The mixture was extracted with $\mathrm{CH}_{2} \mathrm{Cl}_{2}(10 \mathrm{~mL} \times 3)$ and the combined organic extracts were dried over anhydrous $\mathrm{Na}_{2} \mathrm{SO}_{4}$. Concentration in vacuo followed by flash chromatography on silica gel (dichloromethane-methanol, $50: 1)$ afforded 2 (1.75 g, $83 \%$ yield) as a yellow solid. ${ }^{1} \mathrm{H}$ NMR (500 $\left.\mathrm{MHz} \mathrm{CDCl}_{3}\right): \delta 7.47$ (d, $J=7.3 \mathrm{~Hz}, 1 \mathrm{H}), 7.39$ (d, $J=7.6 \mathrm{~Hz}, 1 \mathrm{H}), 7.29$ (t, $J=7.5 \mathrm{~Hz}$, $1 \mathrm{H}), 7.22(\mathrm{t}, J=7.4 \mathrm{~Hz}, 1 \mathrm{H}), 6.44(\mathrm{~s}, 1 \mathrm{H}), 6.39$ (brs, $1 \mathrm{H}), 3.56(\mathrm{~d}, J$ $=16.1 \mathrm{~Hz}, 1 \mathrm{H}), 3.50(\mathrm{~d}, J=16.1 \mathrm{~Hz}, 1 \mathrm{H}), 3.46-3.32(\mathrm{~m}, 3 \mathrm{H})$, 2.56-2.48 (m, 1H), 2.16-2.06 (m, 1H), 1.97 (s, 6H), 1.82-1.68 (m, $2 \mathrm{H}), 1.67-1.58(\mathrm{~m}, 1 \mathrm{H}), 1.34-1.23(\mathrm{~m}, 1 \mathrm{H}), 1.19-1.05(\mathrm{~m}, 2 \mathrm{H})$, 1.04-0.92 (m, 1H). $\left.{ }^{13} \mathrm{C} \mathrm{NMR} \mathrm{(125} \mathrm{MHz} \mathrm{CDCl}_{3}\right): \delta$ 170.5, 144.4, 144.2, 138.6, 131.9, 126.2, 125.0, 123.7, 119.4, 66.4, 51.4, 39.6, 38.0, 36.9, 32.5, 25.3, 24.6, 21.3. HRMS (ESI) calcd for $\mathrm{C}_{19} \mathrm{H}_{27} \mathrm{~N}_{2} \mathrm{O}\left([\mathrm{M}+\mathrm{H}]^{+}\right)$calcd for 299.2123, found 299.2119.

Chiral diamine ligand (3). A solution of $2(0.60 \mathrm{~g}, 2.0 \mathrm{mmol})$ in THF $(20 \mathrm{~mL})$ was added dropwise to a suspension of $\mathrm{LiAlH}_{4}$ $(0.76 \mathrm{~g}, 20 \mathrm{mmol})$ in $\mathrm{THF}(30 \mathrm{~mL})$ at $0{ }^{\circ} \mathrm{C}$ and the resulting mixture was stirred and heated at reflux for 2 days. After being quenched with the addition of $\mathrm{Na}_{2} \mathrm{SO}_{4} \cdot 10 \mathrm{H}_{2} \mathrm{O}$, the suspension was passed through a pad of Celite, eluting with ether. The solvent was removed under reduced pressure and the residue was purified by column chromatography on silica gel (dichloromethane-methanol, $100: 1)$ to give $3(0.39 \mathrm{~g}, 69 \%$ yield) as a yellow oil. $[\alpha]_{\mathrm{D}}^{20}=-66.8\left(c=0.10, \mathrm{CH}_{2} \mathrm{Cl}_{2}\right) \cdot{ }^{1} \mathrm{H} \mathrm{NMR}$ $\left(500 \mathrm{MHz}, \mathrm{C}_{6} \mathrm{D}_{6}\right): \delta 7.35(\mathrm{~d}, J=7.5 \mathrm{~Hz}, 1 \mathrm{H}), 7.31(\mathrm{~d}, J=7.3 \mathrm{~Hz}$, $1 \mathrm{H}), 7.24(\mathrm{t}, J=7.4 \mathrm{~Hz}, 1 \mathrm{H}), 7.15(\mathrm{t}, J=7.5 \mathrm{~Hz}, 1 \mathrm{H}), 6.10(\mathrm{~s}, 1 \mathrm{H})$, 3.18-3.12 (m, 1H), 3.09 (s, 2H), 2.88-2.69 (m, 4H), 2.32-2.21 (m, $2 \mathrm{H}), 2.18-2.11(\mathrm{~m}, 1 \mathrm{H}), 2.01(\mathrm{~s}, 6 \mathrm{H}), 1.66-1.52(\mathrm{~m}, 3 \mathrm{H}), 1.23-1.14$ (m, 1H), 1.13-1.00 (m, 2H), 0.99-0.87 (m, 1H). ${ }^{13} \mathrm{C}$ NMR (75.5 $\left.\mathrm{MHz} \mathrm{CDCl}_{3}\right): \delta 144.3,143.4,141.4,127.6,125.0,123.5,122.7$, 117.9, 65.8, 57.6, 44.8, 38.9, 36.8, 30.9, 27.5, 24.4, 23.7, 19.6. HRMS (ESI) calcd for $\mathrm{C}_{19} \mathrm{H}_{29} \mathrm{~N}_{2}\left([\mathrm{M}+\mathrm{H}]^{+}\right)$calcd for 285.2331, found 285.2328 .

$\left(\eta^{5}: \eta^{1}: \eta^{1}-L\right) Y\left[N\left(S_{i M e}\right)_{2}\right](4 a)$. To a solution of $\left[\left(\mathrm{Me}_{3} \mathrm{Si}\right)_{2} \mathrm{~N}\right]_{3^{-}}$ $\mathrm{Y}(\mu-\mathrm{Cl}) \mathrm{Li}(\mathrm{THF})_{3}(1.33 \mathrm{~g}, 1.6 \mathrm{mmol})$ in toluene $(10.0 \mathrm{~mL})$ was added a solution of $3(0.50 \mathrm{~g}, 1.8 \mathrm{mmol})$ in toluene $(10.0 \mathrm{~mL})$ at room temperature. The resulting mixture was stirred and heated at $75{ }^{\circ} \mathrm{C}$ for $24 \mathrm{~h}$ to give a brown solution. Then, the reaction suspension was filtered to remove the LiCl precipitate. The filtrate was evaporated under vacuum to remove all volatiles to leave a residue solid, which was washed with $n$-hexane $(1 \mathrm{~mL}$ $\times 3)$ and dried under vacuum to afford $4 \mathbf{a}$ as a grey solid ( $0.79 \mathrm{~g}$, $93 \%$ yield). The single crystal suitable for X-ray crystallographic analysis was obtained by recrystallization from a mixed solvent of toluene and THF in volume ratio $20: 1$ at $-10{ }^{\circ} \mathrm{C} .{ }^{1} \mathrm{H}$ NMR $\left(500 \mathrm{MHz}, \mathrm{C}_{6} \mathrm{D}_{6}\right): \delta 7.76(\mathrm{dd}, J=8.4,0.9 \mathrm{~Hz}, 1 \mathrm{H}), 7.38(\mathrm{dt}, J=8.3$, $0.9 \mathrm{~Hz}), 6.95-6.89(\mathrm{~m}, 1 \mathrm{H}), 6.87$ (d, J=3.2 Hz, 1H), 6.85-6.81 (m, $1 \mathrm{H}), 6.30(\mathrm{~d}, J=3.2 \mathrm{~Hz}, 1 \mathrm{H}), 3.93(\mathrm{dd}, J=10.5,7.7 \mathrm{~Hz}, 1 \mathrm{H}), 3.83$ (td, $J=11.2,6.0 \mathrm{~Hz}, 1 \mathrm{H}), 3.56(\mathrm{dd}, J=14.2,5.8 \mathrm{~Hz}, 1 \mathrm{H}), 3.43$ (ddd, $J=14.2,11.5,7.9 \mathrm{~Hz}, 1 \mathrm{H}), 2.78-2.69(\mathrm{~m}, 1 \mathrm{H}), 2.30-2.21$ $(\mathrm{m}, 1 \mathrm{H}), 2.12(\mathrm{td}, J=10.1,3.4 \mathrm{~Hz}, 1 \mathrm{H}), 1.59-1.45(\mathrm{~m}, 5 \mathrm{H}), 1.26-$ $1.18(\mathrm{~m}, 1 \mathrm{H}), 1.12-0.94(\mathrm{~m}, 3 \mathrm{H}), 0.92(\mathrm{~s}, 3 \mathrm{H}), 0.60(\mathrm{qd}, J=12.1$, $3.6 \mathrm{~Hz}, 1 \mathrm{H}), 0.39$ (s, 9H), 0.17 (s, 9H). ${ }^{13} \mathrm{C} \mathrm{NMR}\left(125 \mathrm{MHz}, \mathrm{C}_{6} \mathrm{D}_{6}\right)$ : $\delta 127.4,127.2,123.5,122.1,121.7,121.2,120.7,119.7,93.3,68.1$, 67.0, 60.8, 43.5, 35.0, 32.2, 30.0, 26.1, 25.3, 20.7, 6.1, 4.4. Anal. calcd for $\mathrm{C}_{25} \mathrm{H}_{44} \mathrm{~N}_{3} \mathrm{Si}_{2} \mathrm{Y}: \mathrm{C}, 56.47 ; \mathrm{H}, 8.34 ; \mathrm{N}, 7.90$; found: $\mathrm{C}$, $56.53 ; \mathrm{H}, 8.30 ; \mathrm{N}, 7.82$.

$\left(\eta^{\mathbf{5}}: \eta^{\mathbf{1}}: \eta^{\mathbf{1}}-\mathbf{L}\right) \mathbf{S m}\left[\mathbf{N}\left(\mathrm{SiMe}_{3}\right)_{2}\right] \quad$ (4b). This compound was prepared following a procedure similar to that for $\mathbf{4 a}$ by using $\left[\left(\mathrm{Me}_{3} \mathrm{Si}\right)_{2} \mathrm{~N}\right]_{3} \mathrm{Sm}(\mu-\mathrm{Cl}) \mathrm{Li}(\mathrm{THF})_{3}(1.43 \mathrm{~g}, 1.6 \mathrm{mmol})$ and $3(0.50 \mathrm{~g}$, $1.8 \mathrm{mmol})$ in toluene $(10.0 \mathrm{~mL})$ as a yellow solid $(0.86 \mathrm{~g}, 90 \%$ yield). The single crystal suitable for X-ray crystallographic analysis was obtained by recrystallization from a mixed solvent of toluene and THF in volume ratio $20: 1$ at $-10{ }^{\circ} \mathrm{C}$. ${ }^{1} \mathrm{H}$ NMR $\left(500 \mathrm{MHz}, \mathrm{C}_{6} \mathrm{D}_{6}\right): \delta 17.90(\mathrm{~s}, 1 \mathrm{H}), 13.31(\mathrm{~d}, J=8.5 \mathrm{~Hz}, 1 \mathrm{H}), 10.75$ $(\mathrm{s}, 1 \mathrm{H}), 6.77(\mathrm{~d}, J=6.8 \mathrm{~Hz}, 2 \mathrm{H}), 6.19(\mathrm{~s}, 1 \mathrm{H}), 5.81(\mathrm{~d}, J=7.9 \mathrm{~Hz}$, $1 \mathrm{H}), 4.09(\mathrm{t}, J=7.0 \mathrm{~Hz}, 1 \mathrm{H}), 3.69(\mathrm{~d}, J=12.1 \mathrm{~Hz}, 1 \mathrm{H}), 3.56(\mathrm{~d}, J=$ $13.1 \mathrm{~Hz}, 1 \mathrm{H}), 3.25(\mathrm{~s}, 1 \mathrm{H}), 2.92-2.75(\mathrm{~m}, 2 \mathrm{H}), 2.62(\mathrm{~d}, J=14.2 \mathrm{~Hz}$, $1 \mathrm{H}), 2.49-2.38(\mathrm{~m}, 1 \mathrm{H}), 1.95(\mathrm{~d}, J=12.7 \mathrm{~Hz}, 1 \mathrm{H}), 1.23-1.11(\mathrm{~m}$, $1 \mathrm{H}), 0.68(\mathrm{~s}, 9 \mathrm{H}), 0.30(\mathrm{~s}, 1 \mathrm{H}), 0.10(\mathrm{~s}, 1 \mathrm{H}),-0.30(\mathrm{~s}, 3 \mathrm{H}),-1.65$ (s, 1H), $-2.69(\mathrm{~s}, 3 \mathrm{H}),-3.24(\mathrm{~s}, 9 \mathrm{H}) .{ }^{13} \mathrm{C}$ NMR $\left(125 \mathrm{MHz}, \mathrm{C}_{6} \mathrm{D}_{6}\right)$ : $\delta 131.8,130.5,120.7,117.8,117.2,116.9,112.5$, 92.6, 86.2, 85.3, 82.5, 43.8, 38.4, 32.1, 27.3, 25.6, 23.6, 23.4, 3.5, 2.2, 1.0. Anal. calcd for $\mathrm{C}_{25} \mathrm{H}_{44} \mathrm{~N}_{3} \mathrm{Si}_{2} \mathrm{Sm}$ : C, 50.62; H, 7.48; N, 7.08; found: C, 50.68; H, 7.45; N, 7.02.

$\left(\eta^{\mathbf{5}}: \eta^{\mathbf{1}}: \eta^{\mathbf{1}}-\mathbf{L}\right) \mathbf{L u}\left[\mathbf{N}\left(\mathrm{SiMe}_{3}\right)_{2}\right] \quad$ (4c). This compound was prepared following a procedure similar to that for 4 a by using $\left[\left(\mathrm{Me}_{3} \mathrm{Si}\right)_{2} \mathrm{~N}\right]_{3} \mathrm{Lu}(\mu-\mathrm{Cl}) \mathrm{Li}(\mathrm{THF})_{3}(1.46 \mathrm{~g}, 1.6 \mathrm{mmol})$ and $3(0.50 \mathrm{~g}$, $1.8 \mathrm{mmol})$ as a white solid ( $0.91 \mathrm{~g}, 92 \%$ yield). The single crystal suitable for X-ray crystallographic analysis was obtained by recrystallization from toluene at $-10{ }^{\circ} \mathrm{C} .{ }^{1} \mathrm{H}$ NMR $(500 \mathrm{MHz}$, $\left.\mathrm{C}_{6} \mathrm{D}_{6}\right): \delta 7.76(\mathrm{~d}, J=7.7,1 \mathrm{H}), 7.37(\mathrm{~d}, J=8.4 \mathrm{~Hz}, 1 \mathrm{H}), 6.95-6.89$ $(\mathrm{m}, 1 \mathrm{H}), 6.88-6.76(\mathrm{~m}, 2 \mathrm{H}), 6.24(\mathrm{~d}, J=2.6 \mathrm{~Hz}, 1 \mathrm{H}), 4.06(\mathrm{dd}, J=$ $10.7,7.6 \mathrm{~Hz}, 1 \mathrm{H}), 3.83-3.75(\mathrm{~m}, 1 \mathrm{H}), 3.49$ (dd, $J=14.1,6.1 \mathrm{~Hz}$, $1 \mathrm{H}), 3.42-3.33(\mathrm{~m}, 1 \mathrm{H}), 2.74-2.63(\mathrm{~m}, 1 \mathrm{H}), 2.26-2.19(\mathrm{~m}, 1 \mathrm{H})$, $2.15(\mathrm{td}, J=10.2,3.6 \mathrm{~Hz}, 1 \mathrm{H}), 1.61-1.43(\mathrm{~m}, 4 \mathrm{H}), 1.31-1.21(\mathrm{~m}$, $1 \mathrm{H}), 1.20-1.14(\mathrm{~m}, 1 \mathrm{H}), 1.12-0.77(\mathrm{~m}, 6 \mathrm{H}), 0.60-0.50(\mathrm{~m}, 1 \mathrm{H})$, 0.40 (s, 9H), 0.22 (s, 9H). ${ }^{13} \mathrm{C}$ NMR (125 MHz, $\left.\mathrm{C}_{6} \mathrm{D}_{6}\right): \delta 127.4$, 126.9, 123.5, 122.3, 121.9, 121.4, 119.9, 118.9, 92.6, 67.7, 66.8, $60.8,43.8,34.7,32.2,29.5,26.1,25.3,20.7,6.2,5.1$. Anal. calcd for $\mathrm{C}_{25} \mathrm{H}_{44} \mathrm{~N}_{3} \mathrm{Si}_{2} \mathrm{Lu}$ : C, 48.60; $\mathrm{H}, 7.18 ; \mathrm{N}, 6.80$; found: C, 48.67; $\mathrm{H}$, $7.13 ; \mathrm{N}, 6.74$.

$\left(\eta^{\mathbf{5}}: \eta^{\mathbf{1}}: \eta^{\mathbf{1}}-\mathbf{L}\right) \mathbf{S c}\left[\mathbf{N}\left(\mathrm{SiMe}_{3}\right)_{2}\right] \quad$ (4d). This compound was prepared following a procedure similar to that for $\mathbf{4 a}$ by using $\left[\left(\mathrm{Me}_{3} \mathrm{Si}\right)_{2} \mathrm{~N}\right]_{3} \mathrm{Sc}(\mu-\mathrm{Cl}) \mathrm{Li}(\mathrm{THF})_{3}(1.26 \mathrm{~g}, 1.6 \mathrm{mmol})$ and $(0.50 \mathrm{~g}, 1.8$ $\mathrm{mmol})$, except that the reaction mixture was stirred and heated at $90{ }^{\circ} \mathrm{C}$ for $36 \mathrm{~h}$. The product $4 \mathbf{d}$ was obtained as a purple solid ( $0.73 \mathrm{~g}, 94 \%$ yield). The single crystal suitable for X-ray crystallographic analysis was obtained by recrystallization from a mixed solvent of toluene and THF in volume ratio $20: 1$ at $-10{ }^{\circ} \mathrm{C} .{ }^{1} \mathrm{H}$ NMR $\left(500 \mathrm{MHz}, \mathrm{C}_{6} \mathrm{D}_{6}\right): \delta 7.76-7.69(\mathrm{~m}, 1 \mathrm{H}), 7.37(\mathrm{~d}, J$ 
$=8.3 \mathrm{~Hz}, 1 \mathrm{H}), 6.94-6.88(\mathrm{~m}, 1 \mathrm{H}), 6.87-6.80(\mathrm{~m}, 2 \mathrm{H}), 6.29(\mathrm{~d}, J=$ $3.2 \mathrm{~Hz}, 1 \mathrm{H}), 3.81-3.68(\mathrm{~m}, 2 \mathrm{H}), 3.50-3.42(\mathrm{~m}, 1 \mathrm{H}), 3.42-3.33(\mathrm{~m}$, 1H), 3.04-2.96 (m, 1H), 2.07-1.98 (m, 2H), 1.62 (s, 3H), 1.54-1.46 (m, 2H), 1.23-1.04 (m, 3H), 0.93-0.86 (m, 1H), $0.75(\mathrm{~s}, 3 \mathrm{H}), 0.58-$ $0.48(\mathrm{~m}, 1 \mathrm{H}), 0.41$ (s, 9H), 0.28 (s, 9H). ${ }^{13} \mathrm{C}$ NMR $(126 \mathrm{MHz}$, $\left.\mathrm{C}_{6} \mathrm{D}_{6}\right): \delta 127.0,126.4,123.9,122.2,122.1,121.8,120.9,120.2$, 94.5, 67.0, 60.7, 44.4, 34.1, 31.0, 28.8, 25.5, 24.8, 20.2, 6.2, 6.0. Anal. calcd for $\mathrm{C}_{25} \mathrm{H}_{44} \mathrm{~N}_{3} \mathrm{Si}_{2} \mathrm{Sc}$ : C, 61.56; H, 9.09; N, 8.61; found: C, 61.62; H, 9.03; N, 8.58.

\section{Crystal structure determination}

The single crystal X-ray diffraction data for complexes $\mathbf{4}$ were collected on a diffractometer with graphite monochromated Mo $\mathrm{K} \alpha$ radiation $(\lambda=0.71073 \AA)$ at room temperature. Saint program and SADABS program carried out the data integration. The structures were solved by a direct method and refined on $F^{2}$ using SHELXTL suite of program. All non-hydrogen atoms were anisotropically refined by full-matrix least squares methods. All hydrogen atoms were geometrically generated and isotropically refined using a riding model. Crystallographic data in CIF files are provided in the ESI. $\dagger$ CCDC-1509830 (4a), 1509831 (4b), 1509832 (4c), and 1509833 (4d) contain the supplementary crystallographic data for this paper.

\section{Enantioselective annulative intramolecular hydroamination of olefins catalysed by complexes 4}

In an argon-filled glovebox, $5 \mathrm{~mol} \%$ of $4, \mathrm{Cp}_{2} \mathrm{Fe}(6.0 \mathrm{mg}$, internal standard) and aminoalkene $5(0.32 \mathrm{mmol})$ were weighed into a $5 \mathrm{~mm}$ NMR tube equipped with a Teflon valve (J-Young), and $\mathrm{C}_{6} \mathrm{D}_{6}(0.6 \mathrm{~mL})$ was added. The hydroamination reaction was then monitored by ${ }^{1} \mathrm{H}$ NMR analysis for estimate of both conversion and yield using ferrocene as the internal standard.

\section{Acknowledgements}

Financial support of this research from the National Natural Science Foundation of China (NSFC No. 21672005 and 21472001) and the Special and Excellent Research Fund of Anhui Normal University are gratefully acknowledged.

\section{Notes and references}

1 For recent reviews: (a) P. W. Roesky, Molecular Catalysis of Rare-Earth Elements (Structure and Bonding), Springer, Berlin, 2010; (b) D. Patel and S. T. Liddle, Rev. Inorg. Chem., 2012, 32, 1-22; (c) F. T. Edelmann, Chem. Soc. Rev., 2012, 41, 7657; (d) J. Lucas, P. Lucas, T. L. Mercier, A. Rollat and W. Davenport, Rare Earths, Elsevier, 2015; (e) B. S. Soller, S. Salzinger and B. Rieger, Chem. Rev., 2016, 116, 1993.

2 For selected recent reviews: (a) P. S. Hanley and J. F. Hartwig, Angew. Chem., Int. Ed., 2013, 52, 8510; (b) J. Hannedouche and E. Schulz, Chem.-Eur. J., 2013, 19, 4972; (c) J. Hannedouche, J. Collin, A. Trifonov and E. Schulz, J. Organomet. Chem., 2011, 696, 255; (d) I. Aillaud, J. Collin, J. Hannedouche and E. Schulz, Dalton Trans., 2007, 5105; (e) G. Zi, Dalton Trans., 2009, 9101; (f) T. E. Müller, K. C. Hultzsch, M. Yus, F. Foubelo and M. Tada, Chem. Rev., 2008, 108, 3795; (g) H. Pellissier, Coord. Chem. Rev., 2016, 324, 17.

3 (a) S. Hong and T. J. Marks, Acc. Chem. Res., 2004, 37, 673; (b) J.-S. Ryu, T. J. Marks and F. E. McDonald, J. Org. Chem., 2004, 69, 1038; (c) S. Hong, A. M. Kawaoka and T. J. Marks, J. Am. Chem. Soc., 2003, 125, 15878; (d) S. Hong and T. J. Marks, J. Am. Chem. Soc., 2002, 124, 7886; (e) M. R. Douglass, M. Ogasawara, S. Hong, M. V. Metz and T. J. Marks, Organometallics, 2002, 21, 283; $(f)$ M. A. Giardello, V. P. Conticello, L. Brard, M. R. Gagné and T. J. Marks, J. Am. Chem. Soc., 1994, 116, 10241; (g) M. A. Giardello, V. P. Conticello, L. Brard, M. Sabat, A. L. Rheingold, C. L. Stern and T. J. Marks, J. Am. Chem. Soc., 1994, 116, 10212; (h) M. R. Gagné, L. Brard, V. P. Conticello, M. A. Giardello, C. L. Stern and T. J. Marks, Organometallics, 1992, 11, 2003.

4 D. V. Vitanova, F. Hampel and K. C. Hultzsch, J. Organomet. Chem., 2007, 692, 4690.

5 K. Manna, M. L. Kruse and A. D. Sadow, ACS Catal., 2011, 1, 1637.

6 Z. Chai, D. Hua, K. Li, J. Chu and G. Yang, Chem. Commun., 2014, 50, 177.

7 For examples: (a) D. V. Gribkov, K. C. Hultzsch and F. Hampel, Chem.-Eur. J., 2003, 9, 4796; (b) D. V. Gribkov and K. C. Hultzsch, Chem. Commun., 2004, 730; (c) D. V. Gribkov, K. C. Hultzsch and F. Hampel, J. Am. Chem. Soc., 2006, 128, 3748; (d) A. L. Reznichenko, F. Hampel and K. C. Hultzsch, Chem.-Eur. J., 2009, 15, 12819; (e) A. L. Reznichenko, H. N. Nguyen and K. C. Hultzsch, Angew. Chem., Int. Ed., 2010, 49, 8984; (f) D. V. Vitanova, F. Hampel and K. C. Hultzsch, J. Organomet. Chem., 2011, 696, 321.

8 For recent examples of chiral BINAM-based complexes: $(a)$ A. L. Reznichenko and K. C. Hultzsch, Organometallics, 2013, 32, 1394; (b) A. Aillerie, V. Rodriguez-Ruiz, R. Carlino, F. Bourdreux, R. Guillot, S. Bezzenine-Lafollée, R. Gil, D. Prim and J. Hannedouche, ChemCatChem, 2016, 8, 2455; (c) S. Germain, E. Schulz and J. Hannedouche, ChemCatChem, 2014, 6, 2065; (d) I. Aillaud, C. Olier, Y. Chapurina, J. Collin, E. Schulz, R. Guillot, J. Hannedouche and A. Trifonov, Organometallics, 2011, 30, 3378; (e) Y. Chapurina, H. Ibrahim, R. Guillot, E. Kolodziej, J. Collin, A. Trifonov, E. Schulz and J. Hannedouche, J. Org. Chem., 2011, 76, 10163; (f) K. Huynh, B. K. Anderson and T. Livinghouse, Tetrahedron Lett., 2015, 56, 3658; $(g)$ H. M. Lovick, D. K. An and T. Livinghouse, Dalton Trans., 2011, 7697.

9 For examples of chiral vicinal diamine-based complexes: $(a)$ N. Meyer, A. Zulys and P. W. Roesky, Organometallics, 2006, 25, 4179; (b) P. Benndorf, J. Jenter, L. Zielke and P. W. Roesky, Chem. Commun., 2011, 2574; (c) Y. Zhang, W. Yao, H. Li and Y. Mu, Organometallics, 2012, 31, 4670.

10 (a) P. N. O'Shaughnessy, P. D. Knight, C. Morton, K. M. Gillespie and P. Scott, Chem. Commun., 2003, 1770; (b) P. N. O'Shaughnessy and P. Scott, Tetrahedron: 
Asymmetry, 2003, 14, 1979; (c) P. N. O'Shaughnessy, K. M. Gillespie, P. D. Knight, I. J. Munslow and P. Scott, Dalton Trans., 2004, 2251; (d) S. Hong, S. Tian, M. V. Metz and T. J. Marks, J. Am. Chem. Soc., 2003, 125, 14768; (e) Q. Wang, L. Xiang, H. Song and G. Zi, Inorg. Chem., 2008, 47, 4319; (f) Q. Wang, L. Xiang, H. Song and G. Zi, J. Organomet. Chem., 2009, 694, 691; (g) G. Zi, Q. Wang, L. Xiang and H. Song, Dalton Trans., 2008, 5930; $(h)$ Q. Wang, F. Zhang, H. Song and G. Zi, J. Organomet. Chem., 2011, 696, 2186.

11 For reviews: (a) H. Braunschweig and F. M. Breitling, Coord. Chem. Rev., 2006, 250, 2691; (b) J. Cano and K. Kunz, J. Organomet. Chem., 2007, 692, 4411; (c) S. Arndt and J. Okuda, Chem. Rev., 2002, 102, 1953; for recent examples: (d) N. K. Hangaly, A. R. Petrov, M. Elfferding, K. Harms and J. Sundermeyer, Dalton Trans., 2014, 43, 5930; (e) Z. Jian, N. K. Hangaly, W. Rong, Z. Mou, D. Liu, S. Li, A. Trifonov, J. Sundermeyer and D. Cui, Organometallics, 2012, 31, 4579; (f) Z. Jian, A. R. Petrov, N. K. Hangaly, S. Li, W. Rong, Z. Mou, K. A. Rufanov, K. Harms, J. Sundermeyer and D. Cui, Organometallics, 2012, 31, 4276; (g) Z. Chai, D. Hua, K. Li, S. Zhou, J. Chu and G. Yang, J. Organomet.
Chem., 2014, 768, 136; (h) L. N. Jende, C. O. Hollfelder, C. Maichle-Mössmer and R. Anwander, Organometallics, 2015, 34, 32.

12 For early works on linked $\mathrm{Cp} /$ indene-amido ligands: $(a)$ J. Okuda, S. Verch, R. Stürmer and T. P. Spaniol, J. Organomet. Chem., 2000, 605, 55; (b) J. Okuda, S. Verch, R. Stürmer and T. P. Spaniol, Chirality, 2000, 472; (c) A. L. McKnight, M. A. Masood and R. M. Waymouth, Organometallics, 1997, 16, 2879.

13 (a) E. Sheng, S. Wang, G. Yang, S. Zhou, L. Cheng, K. Zhang and Z. Huang, Organometallics, 2003, 22, 684; (b) S. Zhou, S. Wang, G. Yang, X. Liu, E. Sheng, K. Zhang, L. Cheng and Z. Huang, Polyhedron, 2003, 22, 1019.

14 (a) M. Kaik and J. Gawroński, Tetrahedron: Asymmetry, 2003, 14, 1559; (b) T. Okino, Y. Hoashi and Y. Takemoto, J. Am. Chem. Soc., 2003, 125, 12672; (c) T. Okino, Y. Hoashi, T. Furukawa, X. Xu and Y. Takemoto, J. Am. Chem. Soc., 2005, 127, 119.

15 (a) C. F. Bender and R. A. Widenhoefer, J. Am. Chem. Soc., 2005, 127, 1070; (b) M. R. Crimmin, A. G. M. Barrett, I. J. Casely, M. S. Hill and P. A. Procopiou, J. Am. Chem. Soc., 2009, 131, 9670. 